\title{
UPAYA MENINGKATKAN HASIL BELAJAR PKn MATERI GLOBALISASI MELALUI MODEL PEMBELAJARAN KOOPERATIF TIPE TALKING CHIPS
}

\author{
LILIK SUPRAPTI
}

\author{
Kepala SDN Puri Kec. Puri Kab. Mojokerto \\ Email : liliksuprapti07@gmail.com
}

\begin{abstract}
Abstrak: Jenis penelitian adalah penelitian tindakan kelas yang dilaksanakan selama 2 siklus. Subyek penelitian adalah siswa kelas IV SDN Puri dengan jumlah siswa 30 anak. Penelitian dilakukan dalam 2 siklus, dimana setiap siklus membutuhkan waktu $2 \times 35$ menit dalam waktu 2 minggu pada bulan April 2016. Pengumpulan data diperoleh dari hasil data kualitatif dan kuantitatif. Setelah diterapkannya metode pembelajaran Talking Chips berdasarkan data yang diperoleh dari hasil persiklus, proses pembelajaran berjalan dengan baik dan terbukti efektif baik dalam meningkatkan keaktivan serta kreativitas siswa. Begitu pula dengan peningkatan hasil belajar siswa telah mengalami peningkatan dengan dibuktikannya prosentase nilai di atas KKM (70) pada siklus II mencapai 85\%.
\end{abstract}

Kata kunci : hasil belajar, talking chips, pkn

Pendidikan Kewarganegaraan adalah wahana untuk mengembangkan dan melestarikan nilai luhur yang berakar pada budaya bangsa Indonesia yang diharapkan dapat diwujudkan dalam bentuk perilaku kehidupan sehari-hari siswa. Pelajaran Kewarganegaraan bertujuan untuk mengembangkan pengetahuan dalam memahami dan menghayati nilai Pancasila dalam rangka pembentukan sikap dan perilaku sebagai pribadi, anggota masyarakat, dan warga negara yang bertanggung jawab serta memberi bekal kemampuan untuk mengikuti pendidikan pada jenjang pendidikan selanjutnya.

Pada kenyataannya, PKn dianggap ilmu yang sukar dan sulit dipahami. PKn adalah pelajaran formal yang berupa sejarah masa lampau, perkembangan sosial budaya, perkembangan teknologi, tata cara hidup bersosial, serta peraturan kenegaraan. Begitu luasnya materi PKn menyebabkab anak sulit untuk diajak berfikir kritis dan kreatif dalam menyikapi masalah yang berbeda.

Hal tersebut dirasakan juga di SDN Puri, banyak siswa kurang aktif selama pembelajaraan, siswa kurang memahami konsep pengambilan keputusan bersama, hanya sebagian siswa yang mendominasi setiap pembelajaran, siswa kurang terampil dalam berkomunikasi dengan teman sebaya, yang semua itu menyebabkan hasil belajar siswa rendah. Sehingga banyak yang tidak mampu memenuhi standar ketuntasan. Pada saat diskusi siswa cenderung pasif dan kurang berani mengemukakan pendapatnya. Model pembelajaran yang digunakan kurang efektif dan efesien untuk siswa sehingga siswa kurang menguasi materi tentang globalisasi.Akibat dari pembelajaran yang monoton adalah rendahnya hasil belajar siswa pada pembelajaran PKn. KKM yang telah ditetapkan adalah 70, 
tetapi dari 30 siswa hanya 12 siswa yang telah mencapai KKM dan 18 siswa kurang dari KKM.

Penyebab siswa belum memahami materi pengambilan keputusan bersama karena adanya faktor seperti kurangnya motivasi dari guru, tidak menggunakan alat peraga/media pembelajaran yang menarik perhatian siswa, rendahnya minat baca siswa, guru hanya menggunakan model pembelajaran ceramah sedangkan penjelasan guru terlalu abstrak, kurangnya perhatian siswa ketika pembelajaran berlangsung, pendekatan yang dilakukan guru kurang sesuai, semua siswa yang terlibat dalam pembelajaran saat melakukan diskusi hanya beberapa siswa yang aktif, sedangkan yang lain hanya mendengarkan, kurangnya contoh dan latihan. Untuk itu peran guru dalam pembelajaran diharapkan mempunyai inovasi dalam melakukan model pembelajaran yang lebih kreatif untuk meningkatkan hasil belajar siswa agar memenuhi standar ketuntasan.

Salah satu alternatif model pembelajaran yang kreatif dan inovatif adalah model pembelajaran Kooperatif Tipe Talking Chips.Talking Chips bisa disebut kartu berbicara. Dengan cara ini setiap siswa memiliki tanggung jawab yang sama dalam diskusi sehingga tidak akan ditemukan lagi adanya penumpang gelap (siswa pasif). Model pembelajaran ini merupakan model pembelajaran yang berorientasi berpusat pada siswa. Keunggulan dari model pembelajaran ini adalah untuk mengatasi hambatan pemerataan kesempatan yang sering mewarnai kerja kelompok. Dalam kegiatan Talking Chips masing-masing anggota kelompok mendapat kesempatan untuk memberikan pendapat mereka.

Talking chips adalah sebuah kata yang diambil dari bahasa inggris yang berarti berbicara, sedangkan chips yang berarti kartu. Jadi arti talking chips adalah kartu untuk berbicara. Sedangkan talking chips dalam pembelajaran kooperatif yaitu pembelajaran yang dilakukan dalam kelompok kecil yang terdiri atas 4-5 orang, masing-masing anggota kelompok membawa sejumlah kartu yang berfungsi untuk menandai apabila mereka telah berpendapat dengan memasukkan kartu tersebut ke atas meja. Model pembelajaran talking chips atau kancing gemerincing merupakan salah satu model pembelajaran yang menggunakan metode pembelajaran kooperatif.

Model pembelajaran talking chips dapat digunakan dalam semua mata pelajaran dan untuk semua tingkat usia anak didik. Kegiatan kancing gemerincing membutuhkan pengelompokan siswa menjadi beberapa kelompok. Teknik ini dapat digunakan untuk berdiskusi, mendengarkan pandangan dan pemikiran anggota yang lain ataupun untuk saling mengevaluasi hapalan. Teknik kancing gemerincing dirancang untuk mengatasi hambatan pemerataan kesempatan yang sering mewarnai kerja kelompok. Dalam banyak kelompok, sering ada anggota yang terlalu dominan dan banyak bicara. Sebaliknya juga ada anggota yang pasif dan pasrah saja pada rekannya yang lebih dominan.

Talking chips mempunyai dua proses yang penting, yaitu; proses sosial dan proses dalam penguasaan materi. Proses sosial berperan penting dalam talking chips yang menuntut siswa untuk dapat bekerjasama dalam kelompoknya, sehingga para siswa dapat membangun pengetahuan mereka di dalam suatu bingkai sosial yaitu pada kelompoknya. 
Model Talking Chips sendiri menurut Masitoh dan Laksmi Dewi. (2009:244), terdapat lima langkah utama. Langkah tersebut adalah, (1) Guru menyiapkan kotak kecil yang berisikan kancing-kancing, (2) Setiap siswa dalam kelompok masing-masing mendapatkan dua atau tiga buah kancing, (3) Setiap kali seorang siswa berbicara atau mengeluarkan pendapat ide harus menyerahkan salah satu kancingnya, (4) jika kancing yang dimiliki seorang siswa habis, dia tidak boleh berbicara lagi sampai semua rekannya juga menghabiskan kancing mereka, (5) jika semua kancing sudah habis, sedangkan tugas belum selesai, kelompok boleh mengambil kesepakatan untuk membagi-bagi kancing lagi dan mengulangi prosedurnya kembali.

\section{METODE}

\section{Subjek, Tempat dan Waktu Penelitian}

Subyek penelitian pada mata pelajaran PKn adalah siswa kelas IV SDN

Puri, Kecamatan Puri, Kabupaten Mojokerto Tahun Pelajaran 2014/2015 Spesifikasi sebagai subyek penelitian kelas IV. Dengan jumlah siswa 30 anak yang terdiri dari 16 siswa perempuan dan 14 siswa laki-laki.

\section{Teknik Analisis Data}

Dalam kegiatan pengumpulan data ini, penulis dibatu teman sejawat selaku supervisor 2. Pengamatan ini dilakukan pada saat berlangsungnya pelaksanaan perbaikan pembelajaran pada mata pelajaran PKn materi globalisasi di kelas IV SDN Puri. Adapun data-data yang diperoleh adalah hasil data kualitatif dan kuantitatif.

\section{Hasil data kualitatif}

Dalam kegiatan pengumpulan data secara kualitatif, pengamat menggunakan lembar observasi guru. Pengamat memberikan tanda cek $(\sqrt{ })$ pada kolom kemunculan sesuai indikator tersebut.

Pengamatan yang dilakukan oleh pengamat (supervisor 2) adalah tentang keefektifan metode pembelajaran Talking Chips dalam meningkatkan hasil belajar siswa dalam pembelajaran PKn materi globalisasi di kelas IV SDN Puri . Untuk mendapatkan data yang lebih tepat, maka fokus pengamatan ditekankan pada: (1) kegiatan guru dalam menerapkan metode pembelajaran Talking Chips, (2) Aktifitas siswa selama pembelajaran menggunakan metode pembelajaran Talking Chips.

\section{Hasil data kuantitatif}

Penelitian kuantitatif melibatkan diri pada perhitungan atau angka atau kuantitatif (Moleong, 2004:3). Data kuantitatif diperoleh dari hasil nilai lembar kerja siswa. Dari hasil tersebut dapat digunakan untuk mengukur tingkat keberhasilan pembelajaran. Dari hasil nilai tersebut dapat diketahui tingkat keberhasilan penggunaan metode pembelajaran Talking Chips dalam meningkatkan hasil belajar siswa. 


\section{HASIL \& PEMBAHASAN}

Pembelajaran prasiklus mata pelajatan PKn materi globalisasi kelas IV SDN Puri, Kecamatan Puri dilaksanakan pada Selasa, 07 April 2015 hasilnya belum memuaskan, siswa yang mendapat nilai di atas 70 sebanyak 12 siswa sedangkan nilai kurang dari 70 sebanyak 18 siswa.

Perbaikan pembelajaran siklus I dilaksanakan pada hari Selasa, 14 April 2015 dengan subjek siswa kelas IV SDN Puri, Kecamatan Puri. Dengan dibantu teman sejawat selaku observator 2. Peneliti melaksanakan sesuai rencana. Skenario pembelajaran berlangsung dengan baik. Peneliti melaksanakan sesuai rencana. Pada akhir pembelajaran peneliti mengadakan penilaian untuk mengetahui tingkat keberhasilanterdapat 18 siswa mencapai nilai diatas 70 dan 12 siswa mendapat nilai kurang dari 70. Hasil penilaian siklus I diperoleh setelah pelaksanaan perbaikan pembelajaran siklus I selesai.

Pada pembelajaran perbaikan siklus I dengan menggunakan lembar observasi diperoleh data bahwa: (1) Penjelasan materi sangat cepat sehingga kurang dimengerti siswa, (2) Siswa kurang terampil dalam menggunakan Metode Talking Chips, (3) Guru kurang memberikan bimbingan kepada siswa.

Dari hasil pengamatan, guru mengadakan refleksi untuk mengetahui kekurangan, hambatan dan kendala yang terjadi pada proses pembelajaran. Perbaikan pembelajarn tahap berikutnya yang menjadi fokus perbaikan adalah sebagai berikut: (1) Memberikan materi yang jelas dan lengkap sehingga siswa mudah memahami, (2) Memotivasi siswa agar lebih terampil dalam menggunakan metode Talking Chips, (3) Memberikan bimbingan pada siswa yang membutuhkan.

Perbaikan pembelajaran siklus II dilaksanakan pada hari Selasa, 21 April 2015 Skenario pembelajaran berlangsung dengan baik. Peneliti melaksanakan sesuai rencana. Pada akhir pembelajaran peneliti mengadakan penilaian untuk mengetahui tingkat keberhasilan, terdapat 23 siswa mencapai nilai diatas 70 dan 7 siswa mendapat nilai kurang dari 70.

Pada pembelajaran perbaikan siklus II dengan menggunakan lembar observasi. Dalam proses ini diperoleh data bahwa: (1) Penyampaian materi disampaikan dengan baik sehingga siswa memahami materi, (2) Siswa sudah berani bertanya pada guru jika mengalami kesulitan, (3) siswa terampil dalam menggunakan Talking Chips.

Pada tahap siklus 2, guru sudah mulai bisa membangun kegiatan apersepsi yang bisa memotivasi siswa untuk belajar, selain itu siswa lebih mudah memahami materi yang disampaikan oleh guru. Siswa sudah mulai menunjukkan sikap yang realistis yaitu aktif bertanya tentang materi yang belum dipahami dan saling bertukar pendapat dengan menggunakan Talking Chips mengenai materi Globalisasi, sehingga proses belajar mengajar lebih menyenangkan, tidak membosankan dan siswa lebih mudah menyerap informasi (materi) dari pembelajaran yang disampaikan.

Perolehan rentang nilai 90 - 100 terus meningkat tiap siklusnya, rentang nilai 80 - 89 mengalami peningkatan $4 \%$ dari siklus I ke siklus II, sedangkan rentang nilai $70-79$ menunjukkan peningkatan yang signifikan yaitu $18 \%$ dari 
siklus I ke siklus II. Bahkan pada siklus II prosentase rentang nilai $90-100$ menduduki peringkat tertinggi dibanding dengan rentang nilai yang lain.

\section{KESIMPULAN}

Adapun kesimpulan dari penelitian ini adalah (1) Proses pembelajaran melalui metode Talking Chips tahun pelajaran 2015 - 2016 berjalan dengan baik dan terbukti efektif baik dalam meningkatkan keaktifan serta kreatifitas siswa dalam pembelajaran juga dapat meningkatkan daya ingat siswa. Hal ini terbukti dari hasil pengamatan setiap siklusnya. Dimana siswa yang menunjukkan aktifitas pasif mengalami penurunan setiap siklusnya. (2) Peningkatan hasil belajar melalui metode Talking Chips tahun pelajaran 2015 - 2016 telah mengalami peningkatan dengan dibuktikannya prosentase nilai diatas KKM (70) dari tiap siklus mengalami peningkatan. Terbukti dari prosentase peningkatan nilai prasiklus dengan siklus I meningkat $16 \%$ dan dari siklus I dengan siklus II meningkat 14 $\%$.

\section{SARAN}

Adapun saran tindak lanjut adalah sebagai berikut: (1) bagi guru diharapkan lebih memperhatikan kesiapan guru dalam mengkondisikan siswa di kelas agar selama prose KBM berlangsung dengan kondusif. (2) bagi sekolah diharapkan dapat memberikan kesempatan kepada seluruh guru untuk melakukan penelitian tindakan kelas dengan berbagai metode pembelajaran dan memberikan arahan serta dukungan untuk memaksimalkan kualitas belajar siswa.

\section{DAFTAR PUSTAKA}

Aina, Mulyana. 2015. Model pembelajaran tipe Talking Chips.Diunduh 25 Maret 2016 dari http://ainamulyana.blogspot.co.id/2015/09/model-modelpembelajaran.inovatif-dan.html.

Anitah W, Sri. 2014. Strategi Pembelajaran di SD. Tangerang Selatan: Universitas Terbuka.

Anita Lie. 2002. Cooperative Learning (Mempraktekkan Cooperative Learning di ruang kelas ). Jakarta: PT Gramedia Widiasarana.

Arikunto, Suharsimi. 1997. Dasar- dasar Evaluasi Pendidikan. Jakarta: Bumi Aksara.

Kondang, Andry. 2013. 40 Macam Model Pembelajaran Efektif. Diunduh 01 Agustus 2013 dari http://anndry7.blogspot.com/2013/08/40-macampembelajaran-efektif.html?m=1.

Moleong, Lexy J. 2005. Metode Penelitian Kualitatif. Bandung: PT.Remaja Rosdakarya. 
Soetomo. 1993. Dasar- Dasar Interaksi Belajar Mengajar. Surabaya: Usaha Nasional

Tim-FKIP UT. 2014. Pemantapan Kemampuan Profesional. Tangerang Selatan : Universitas Terbuka.

Tim Penyusun Kamus Pustaka Pembinaan dan Pengembangan Bahasa. 1989. Kamus Besar Bahasa Indonesia. Jakarta : Balai Pustaka.

Wardani, IG.A.K dkk. 2013. Prespektif Pendidikan SD. Tangerang Selatan : Universitas Terbuka.

Wardani, IG.A.K dan Wihardit, Kuswaya. ( 2014 ). Penelitian Tindakan Kelas. Tangerang Selatan: Universitas Terbuka.

Winataputra, Udin S. (2012). Pembelajaran PKn di SD. Tangerang Selatan: Universitas Terbuka. 